\title{
Screening of Faba Bean Lines against Black Root Rot Caused by Fusarium solani
}

\author{
Belay Habtegebriel ${ }^{1 *}$ and Anteneh Boydom² \\ ${ }^{1}$ Ethiopian Institute of Agricultural Research, Ethiopia \\ ${ }^{2}$ Ethiopian Institute of Agricultural Research, Holleta Agricultural Research Center, Ethiopia
}

Submission: September 06, 2017; Published: January 08, 2018

"Corresponding author: Belay Habtegebriel, Plant Protection Research Center, 1Ethiopian Institute of Agricultural Research, Ethiopia, Ambo, Ethiopia, Email: belayhw@yahoo.com

\begin{abstract}
Faba bean root rot caused by Fusarium solani is one of the most important diseases constraining its production in the major growing areas in Ethiopia. Thirty faba bean lines obtained from Kulumsa Agricultural Research Center were evaluated for resistance against root rot on a well developed sick plot at Ambo Plant Protection Research Center for two consecutive years. Seeds of the accessions were sown in single and double rows. Mortality was recorded at emergence, seedling, podding and maturity. Results showed that 10 of the accessions (EHO7005, EHO7017, EHO7019, EHO7020, EHO7022, EHO7024, EHO7025, EHO7026, OBSE and GEBELECHO) were found to be moderately susceptible while the remaining 20 showed highly susceptible reactions. The moderately susceptible accessions may be considered for further improvement. The highly susceptible accessions should not be used in faba bean improvement programs for vertisols.
\end{abstract}

\section{Introduction}

The total cultivated land allocated for faba bean in Ethiopia is 457,559 ha with total production of 7, 147,960 quintals and the national average yield is 15.62 quintals/ha [1]. The production of faba bean (Vicia faba L) is constrained by several biotic and abiotic stresses and black root rot caused by Fusarim solani (Mart) Appel \& Wollenw is one of the most important biotic stresses in the major faba bean growing areas [2,3]. Field grown beans are highly destructed by Fusarium solani [4]. According to Stewart \& Dagnachew [5] and Habtu \& Dereje [6], in severe conditions on farmers' fields, annual yield loss due to wilt and root rots can reach up to $70 \%$. When favorable conditions prevail and sever infections occur, the disease can cause complete crop loss [7].

Although there are management options such as rotation with non-susceptible crops, good soil drainage and use of disease free or fungicide treated seeds, none of these are able to contain the disease adequately in the field [8]. Use of resistant varieties is the most inexpensive and sustainable management option for the control of faba bean root rots. As a result of efforts made through national and regional faba bean improvement programs, four resistant varieties: Wayu (Wayu 89-5), Selale (Selale Kasim 91-13), Lalo (Selale Kasim 89-4) and Dagm (Grarjarso 89-8) were developed and released in 2002 [9]. Through time, varietal resistances tend to break. To overcome this problem, screening of more varieties is invaluable. The objective of this study was therefore to evaluate nationally available faba bean lines for resistance to the disease especially in vertisols.

\section{Materials and Methods}

Thirty F2 generation faba bean lines obtained from Kulumsa Agricultural Research Center (Table 1) were evaluated in a well developed sick plot at Ambo Plant Protection Research Center. To increase the inoculums load of the sick plot, the Pathogen was artificially mass produced on faba bean seeds and applied to the sick plot. In addition to this, a susceptible local faba bean variety "kassa" was sown during the short rainy season and ploughed to be incorporated into the soil after showing symptoms of the disease. Twenty nine of the lines were sown on plot size of $2 \mathrm{~m} \mathrm{x}$ $0.8 \mathrm{~m}$ with four rows per entry and 20 seeds per row while one line (EHO 7001) was sown in two rows. The distance between plants was $10 \mathrm{~cm}$. The susceptible check (kassa) was planted every two test rows. Incidence was recorded at emergence, seedling podding, and maturity and mortality was assessed using 1-9 scale [10]. DAP was applied at a rate of $100 \mathrm{~kg} / \mathrm{ha}$ at planting. The experiment was conducted during two consecutive main rain seasons of 2009/10 and 2010/11. 
Results and Discussion

Table 1: Reaction of faba bean lines for root rot caused by F. solani as evaluated in sick plot during the main rainy seasons of $2009 / 2010$ and 2010/2011.

\begin{tabular}{|c|c|c|c|c|c|c|c|}
\hline Line & $\begin{array}{c}\text { Disease Score } \\
\text { (1-9) Scale and } \\
\% \text { Mortality }\end{array}$ & & & & Mean Score & $\begin{array}{c}\text { Mean } \\
\text { Mortality\% }\end{array}$ & Reaction \\
\hline & $2009 / 2010$ & & $2010 / 2011$ & & & & \\
\hline & Score & Mortality & Score & Mortality & & & \\
\hline EH07001 & 9 & 68.07 & 7 & 45.24 & 8 & 56.65 & $\begin{array}{c}\text { Highly } \\
\text { susceptible }\end{array}$ \\
\hline EHO7002 & 9 & 53.85 & 8 & 85 & 8.5 & 69.42 & $\begin{array}{c}\text { Highly } \\
\text { susceptible }\end{array}$ \\
\hline EHO7003 & 9 & 96.52 & 8 & 50.63 & 8.5 & 73.58 & $\begin{array}{c}\text { Highly } \\
\text { susceptible }\end{array}$ \\
\hline EHO7004 & 9 & 94.81 & 8 & 70.51 & 8.5 & 82.66 & $\begin{array}{c}\text { Highly } \\
\text { susceptible }\end{array}$ \\
\hline EH07005 & 7 & 44.59 & 8 & 65.43 & 7.5 & 55.01 & $\begin{array}{l}\text { Moderately } \\
\text { susceptible }\end{array}$ \\
\hline EH07006 & 9 & 92.5 & 7 & 40.51 & 8 & 66.5 & $\begin{array}{c}\text { Highly } \\
\text { susceptible }\end{array}$ \\
\hline EHO7007 & 9 & 53.89 & 8 & 66.67 & 8.5 & 60.28 & $\begin{array}{c}\text { Highly } \\
\text { susceptible }\end{array}$ \\
\hline EHO7008 & 9 & 90 & 7 & 50 & 8 & 70 & $\begin{array}{c}\text { Highly } \\
\text { susceptible }\end{array}$ \\
\hline EHO7009 & 9 & 95.36 & 7 & 48.75 & 8 & 72.06 & $\begin{array}{c}\text { Highly } \\
\text { susceptible }\end{array}$ \\
\hline EH07010 & 9 & 90 & 7 & 41.98 & 8 & 65.99 & $\begin{array}{c}\text { Highly } \\
\text { susceptible }\end{array}$ \\
\hline EH07011 & 9 & 92.41 & 9 & 83.12 & 9 & 87.76 & $\begin{array}{c}\text { Highly } \\
\text { susceptible }\end{array}$ \\
\hline EH07012 & 9 & 58.23 & 9 & 91.25 & 9 & 74.74 & $\begin{array}{c}\text { Highly } \\
\text { susceptible }\end{array}$ \\
\hline EH07013 & 9 & 93.38 & 8 & 72.15 & 8.5 & 82.76 & $\begin{array}{c}\text { Highly } \\
\text { susceptible }\end{array}$ \\
\hline EH07014 & 9 & 93.33 & 8 & 52.5 & 8.5 & 72.92 & $\begin{array}{c}\text { Highly } \\
\text { susceptible }\end{array}$ \\
\hline EH07015 & 9 & 100 & 9 & 81.16 & 9 & 90.58 & $\begin{array}{c}\text { Highly } \\
\text { susceptible }\end{array}$ \\
\hline EH07016 & 9 & 94.64 & 8 & 60 & 8.5 & 77.32 & $\begin{array}{c}\text { Highly } \\
\text { susceptible }\end{array}$ \\
\hline EH07017 & 9 & 97.01 & 6 & 29.73 & 7.5 & 63.37 & $\begin{array}{l}\text { Moderately } \\
\text { susceptible }\end{array}$ \\
\hline EH07018 & 9 & 64.91 & 7 & 44.59 & 8 & 54.75 & $\begin{array}{c}\text { Highly } \\
\text { susceptible }\end{array}$ \\
\hline EH07019 & 9 & 93.1 & 6 & 29.87 & 7.5 & 61.49 & $\begin{array}{l}\text { Moderately } \\
\text { susceptible }\end{array}$ \\
\hline EH07020 & 9 & 98.68 & 6 & 35 & 7.5 & 66.84 & $\begin{array}{l}\text { Moderately } \\
\text { susceptible }\end{array}$ \\
\hline EH07021 & 9 & 72.57 & 7 & 41.33 & 8 & 56.95 & $\begin{array}{c}\text { Highly } \\
\text { susceptible }\end{array}$ \\
\hline EH07022 & 9 & 94.67 & 6 & 29.87 & 7.5 & 62.27 & $\begin{array}{l}\text { Moderately } \\
\text { susceptible }\end{array}$ \\
\hline EH07023 & 9 & 97.06 & 7 & 38.36 & 8 & 67.71 & $\begin{array}{c}\text { Highly } \\
\text { susceptible }\end{array}$ \\
\hline
\end{tabular}


Agricultural Research \& Technology: Open Access Journal

\begin{tabular}{|c|c|c|c|c|c|c|c|}
\hline EH07024 & 7 & 40.26 & 7 & 42.86 & 7 & $\begin{array}{c}\text { Moderately } \\
\text { susceptible }\end{array}$ \\
\hline EH07025 & 9 & 70 & 5 & 17.81 & 7 & $\begin{array}{c}\text { Moderately } \\
\text { susceptible }\end{array}$ \\
\hline EHO7026 & 9 & 97.06 & 6 & 27.14 & 7.5 & $\begin{array}{c}\text { Moderately } \\
\text { susceptible }\end{array}$ \\
\hline MOTTI & 9 & 94.29 & 7 & 41.18 & 8 & 62.1 & $\begin{array}{c}\text { Highly } \\
\text { susceptible }\end{array}$ \\
\hline GEBELECHO & 9 & 92.65 & 6 & 33.82 & 7.5 & 63.24 & $\begin{array}{c}\text { Moderately } \\
\text { susceptible }\end{array}$ \\
\hline OBSE & 9 & 88.24 & 6 & 33.82 & 7.5 & 61.03 & $\begin{array}{c}\text { Moderately } \\
\text { susceptible }\end{array}$ \\
\hline WOLKI & 9 & 68.63 & 9 & 69.86 & 9 & 69.25 & Highly \\
susceptible \\
\hline
\end{tabular}

The reactions of the evaluated faba bean lines are given in table 1 . Ten of the lines showed a moderately susceptible reaction with mean disease score of 6-7 (mortality of $20-50 \%$ ). The remaining 20 lines were highly susceptible to root rot due to Fusarium solani with mean score of $8-9$ (mortality of $>50 \%$ ). The evaluated lines are susceptible to the disease. However, in case of good agronomic performances such as high yield, the moderately susceptible lines may be considered for further improvement in terms of resistance to root rot. The highly susceptible lines should not be used in faba bean improvement programs for vertisols. In general, from the year 2000- 2006, 1578 entries were tested out of which 82 showed resistances to root rot. However, only 19 lines showing less than $20 \%$ mortality were selected for further improvement by breeders [11]. The current screening evaluated only 30 lines which is much less compared to previous studies. The study revealed that almost all the lines are susceptible to the root rot pathogen, indicating that there is a need to strengthen the search for more root rot resistant varieties.

\section{Acknowledgement}

The authors are highly indebted to Ato Bedasso Jebessa who assisted in the screening of the lines relentlessly. We also thank Kulumsa and Hollota Agricultural research centers for the supply of the faba bean lines. This research work was funded by the Ethiopian Institute of Agricultural Research (EIAR) regular budget.

\section{References}

1. CSA (2011/2012) Agricultural Sample Survey: Report on area and production of crops. Addis Ababa, Central Statistics Authority, Ethiopia.
2. Beshir T (1995) Development of wilt / root rot resistant cultivars in faba bean. In: Eshetu B, Abdurahman A, Aynekulu Y. (Eds.), Proceedings of the third Annual Conference of Crop Protection Society of Ethiopia, CPSE, Addis Ababa, Ethiopia.

3. Beshir T (1999) Evaluation of the potential of Trichoderma viride as biological control agent of Root rot disease, Fusarium solani, of faba bean. Pest Management Journal of Ethiopia 3(1 \& 2): 91-94.

4. Akrami M, Ibrahimov A Sh, Zafari DM, Valizadeh E (2009) Control of Fusarium Rot of Bean by Combination of Trichoderma harzianum and Trichoderma asperillum in Greenhouse Conditions. Agricultural Journal 4(3): 121-123.

5. Stewart RD, Yirgu D (1967) Index of plant diseases in Ethiopia. Experimental Station Bull. No. 30, HISU. College of Agriculture, Debre- Zeit, p. 95.

6. Asefa H, Gorfu D (1985) A review of food legume disease research in Ethiopia. In: Tsedeke Abate (Ed.), A review of Crop Protection Research in Ethiopia. Addis Ababa, Ethiopia, pp. 345-500.

7. Negusse T, Seid A, Dereje G, Tesfaye T, Chemeda F, et al. (2008) Review of research on diseases of food legumes. In: Abraham Tadesse (Ed.) 2008. Increasing crop production through improved plant protectionVol. I. Proceedings of the $14^{\text {th }}$ Annual conference of the plant protection society of Ethiopia (PPSE) 19-22 December 2006. PPSE and EIAR. Addis Ababa, Ethiopia.

8. Agrios GN (2005) Plant Pathology. ( $5^{\text {th }}$ edn), Elsevier Academic Press, London, UK, England.

9. NAIA (2003) Crop variety register. National Agricultural Input authority of Ethiopia, Ethiopia.

10. Nene YL, Haware MP, Reddy MV (1981) Chickpea Diseases. Resistance Screening Techniques. Information Bulletin No. 10. pp. 5-10.

11. PPRC (Plant Protection Research Center) (2007) Completed Research Activities. Institute of Agricultural Research, Ambo, Ethiopia. 
Your next submission with Juniper Publishers will reach you the below assets

- Quality Editorial service

- Swift Peer Review

- Reprints availability

- E-prints Service

- Manuscript Podcast for convenient understanding

- Global attainment for your research

- Manuscript accessibility in different formats

( Pdf, E-pub, Full Text, Audio)

- Unceasing customer service

Track the below URL for one-step submission https://juniperpublishers.com/online-submission.php 